\title{
Biodiversity and forage behavior of bees in Italian pumpkin crop (Cucurbita pepo)
}

Darclet Teresinha Malerbo-Souza ${ }^{1}$, Milena Oliveira de Andrade ${ }^{1}$, Núbia Maria Guedes Medeiros ${ }^{1}$, Thulio Gustavo da Silva ${ }^{1}$, Rodrigo Alves de Siqueira ${ }^{2}$

1 Professora Adjunta, Departamento de Zootecnia, Universidade Federal Rural de Pernambuco, Recife, PE.

2 Graduandos em Zootecnia, Universidade Federal Rural de Pernambuco, Recife, PE

*Autora para correspondência: darclet.malerbo@ufrpe.br

\begin{abstract}
The aim of this experiment was to study the biodiversity of pollinators in Italian pumpkin crop in 2013, 2014 and 2015 , in relation to the visiting insects in male and female flowers, the type of collection and their forage behavior, in Ribeirão Preto, SP. The opening and closing of flowers and the attractiveness of the male flowers to the female flowers were evaluated. The frequency and type of collection of flower visitors were obtained by counting in the first 10 minutes of each hour with three replicates in each year. Was observed that the flowers open at 6:00 a.m. and closed about 1:00 p.m. The female flowers begin to close at 12 noon and soon after the male ones close also, reducing the activity of the pollinators. Several bee species collect nectar and pollen from pumpkin flowers: Africanized honey bees Apis mellifera, stingless bees Trigona spinipes, native bees Exomalopsis analis, Peponapis fervens and species of the family Halictidae. The most frequent insect in the flowers was Africanized honey bee $(79.25 \%)$ followed by the stingless bee Trigona spinipes (20.75\%). The honey bee visited the flowers from 7:00 a.m. to 1:00 p.m. and preferred to collect nectar in male flowers $(61.0 \%)$ when compared to pollen in male flowers $(22.3 \%)$ and nectar in female flowers (16.7\%). Due to forage behavior all bees observed were considered as pollinators of the Italian pumpkin crop.
\end{abstract}

Keywords: insects; cucurbits; pollination.

\section{Biodiversidade e comportamento forrageiro de abelhas na cultura da aboboreira italiana (Cucurbita pepo)}

\section{Resumo}

Os objetivos deste trabalho foram estudar os polinizadores da abóbora-italiana, em 2013, 2014 e 2015, quanto aos insetos visitantes nas flores, o tipo de coleta e comportamento forrageiro, em Ribeirão Preto, SP. O horário de abertura e fechamento e a atratividade das flores masculinas com relação às femininas foram avaliados. A frequência das visitações dos insetos e o tipo de coleta nas flores, no decorrer do dia, foram obtidos por meio de contagem, nos primeiros 10 minutos de cada horário, com três repetições em cada ano estudado. O comportamento forrageiro de cada espécie de inseto foi avaliado através de observações visuais, no decorrer do dia, durante todo o período experimental. Observou-se que as flores se abrem às $6 \mathrm{~h} 00$, permanecendo abertas até por volta das $13 \mathrm{~h} 00$. A partir das $12 \mathrm{~h} 00$, as flores femininas começam a fechar e logo após as masculinas fecham também, reduzindo a atividade dos polinizadores. Várias espécies de abelhas coletaram néctar e pólen das flores da abóbora: abelhs africanizadas Apis mellifera, abelhas sem ferrão Trigona spinipes, abelhas nativas Peponapis fervens e espécies da família Halictidae. $O$ inseto mais frequente nas flores foi abelha africanizada $(79,25 \%)$ seguida da abelha sem ferrão Trigona spinipes (20,75\%). A abelha africanizada visitou as flores das 7 h00 às $13 \mathrm{~h} 00$ e preferiu coletar néctar nas flores masculinas $(61,0 \%)$, quando comparado a pólen $(22,3 \%)$ e néctar nas femininas $(16,7 \%)$. Pelo comportamento, as abelhas observadas foram consideradas polinizadoras dessa cultura.

Palavras-chave: insetos; cucurbitáceas; polinização. 


\section{Introduction}

Pollination is considered a regulatory, provisional and cultural ecosystem service, being an ecological interaction that provides many benefits to humans, include the maintenance and genetic variability of plant populations biodiversity, ecosystem functions (regulatory ecosystem service), ensuring reliable, diversified supply of fruits, seeds, honey, among others (ecosystem service provision) and the promotion of values cultural aspects related to traditional knowledge (cultural ecosystem service) (IPBES, 2016, COSTANZA et al., 2017). The potential of pollination as an ecosystem service can be highlighted when associated with food production. The first global economic assessment of the pollination ecosystem service pointed to the US $\$ 70$ billion per year (COSTANZA et al., 1997). More recently, this ecosystem service was valued at $€ 153$ billion (GALLAl et al., 2009). This number has been updated in the Pollinator, Pollination and Food Production Assessment Report of the IPBES, estimated between US \$ 235 billion and US $\$ 577$ billion (IPBES, 2016). The pollination related to agricultural production has an annual value of US $\$ 12$ billion in Brazil (GIANNINI et al., 2015).

Pollination is performed by animals, wind, water or both of them. Most of the plants cultivated or native are pollinated by animals and depend on them for their reproduction (ROUBIK, 2018). In tropical communities $94 \%$ of the plants are pollinated by animals (OLLERTON et al., 2011). Pollinator animals are mostly insects such as bees, flies, butterflies, moths, wasps, beetles and thrips, but there are also vertebrate pollinators such as birds, bats, non-flying mammals and lizards. Bees are the most abundant group of pollinators in agriculture, as they visit more than $90 \%$ of the 107 main agricultural crops studied in the world (KLEIN et al., 2007). Considering only the cultivated plants pollinated by animals, $70 \%$ of the total of 1,330 crops in the tropical regions produce fruits and seeds in greater quantity and / or better quality when properly pollinated (ROUBIK, 2018).

The Cucurbitaceae family has 90 genera and 750 species adapted to the tropical and subtropical regions with several species of economic importance and for food such as Italian pumpkin, Cucurbita pepo. The Cucurbita species are monoic flowers and dependent on biotic vectors to ensure pollination (KRUG et al., 2010).
Signs of adequate pollination can be visualized on fruits and pods: symmetrical fruits, fully developed, satisfactory weight, uniform set and pods with many seeds with good germination. The quantitative and qualitative production of fruits has been used to demonstrate the value of bees in pollination (BARÔNIO et al., 2016).

Several species of cucurbits are used in human food: Cucurbita pepo (italian pumpkin) $C$. moschata (pumpkin), C. maxima (squash), Sechium edulis (chayote), Citrullus lanatus (watermelon), Cucumis melo (melon) and $C$. sativus (cucumber) and $C$. anguria (gherkin) that present great commercial value. Besides the bush (Luffa cylindrica), much used as a bath sponge.

Several works attribute to different insects as pollinator of pumpkins. In Brazil, Ávila et al. (1989) reported Trigona sp. as pollinators, however, to a lesser extent than Africanized honey bees. Lattaro and Malerbo-Souza (2006) observed that the most frequent insect visiting $C$. pepo flowers was Africanized honey bee. Artz and Nault (2011) compared the pollination services in C. pepo, supplied by $A$. mellifera and two native bee species, Bombus impatiens and Peponapis pruinosa, in New York, USA, from 2008 to 2010 and determined the pollen deposition in a single visit, visits with contact with stigma, time in flower, fruit, seed, and fruit weight by number of visits. These authors observed that the $A$. mellifera spent two to three times longer on each flower compared to $B$. impatiens and $P$. pruinosa, and visited female flowers 10-20 times longer than the native ones. However, $B$. impatiens deposited three times more pollen grains per stigma and contacted stigmas significantly more times than A. mellifera or $P$. pruinosa. Krug et al. (2010), analyzing cucurbits cultivated in seven different locations in Santa Catarina state, southern Brazil, observed that the most abundant species of bees were Africanized honey bee (32\%) followed by $P$. fervens (25\%).

Therefore, the aim of this experiment was to study the biodiversity and forage behavior of bees in Italian pumpkin crop (C. pepo) in 2013, 2014 and 2015, in Ribeirão Preto, SP, Brazil.

\section{Material and Methods}

This experiment was conducted in the Moura Lacerda University Center campus, in the city of Ribeirão Preto, in the state of São Paulo, Brazil. The altitude were 544 meters with the 
following geographic coordinates 200 33 '26" South latitude and 48 34' 04" West longitude with temperate subtropical climate (KöppenGeiger climatic classification: Aw), average temperature annual around $21^{\circ} \mathrm{C}$ and average annual rainfall of $1,500 \mathrm{~mm}$.

The Italian pumpkin crop (Cucurbita pepo) was installed in June 2013, June 2014 and June 2015 in area of $400 \mathrm{~m}^{2}(50.0 \times 8.0 \mathrm{~m})$ spaced $2.0 \mathrm{~m}$ between plants and $3.0 \mathrm{~m}$ between rows. In studied years the culture was observed throughout the period of flowering and fruiting. The soil of the experimental area is characterized as clayey and a drip irrigation system was used in the planting lines. Fertilization in pits was also carried out using Bulletin 100 along with soil analysis. Subsequently, four applications were made by fertigation.

In the three years, to study the flower cycle were made observations to establish the duration of the flower from the moment of its opening to complete wilting and fruiting. For this 30 flowers were marked, with half (15) of male flowers and the other half of female flowers with three replications, for a total of 90 flowers per year. The total time of flowering of this crop was observed. Of the plants used in the trial 12 were randomly taken for flower counts. The flowers were counted three times (three different days) during flowering and the number of male and female flowers was also distinguished.

The frequency of the visits and the type of collection (nectar or pollen) of the insects in the male and female flowers of Italian pumpkin were obtained by counting from 7:00 a.m. to 6:00 p.m., 10 minutes at each hour through visual observation with three replications (three different days) in each studied year (2013, 2014 and 2015). The attractiveness of male flowers to female flowers was evaluated by observing the percentage of insects present in these flowers during the day with three replicates (distinct days) in each studied year too.

The constancy $(C)$ of these insects was obtained by means of the formula: $C=(P \times 100) /$ $N$, where $P$ is the number of collections containing the species studied and $\mathrm{N}$ is the total number of collections made (SILVEIRA-NETO et al., 1976).

The foraging behavior of each species of insect was evaluated through visual observations, during the day, during the experimental period, during the three years. The visiting insects of the flowers were identified in comparison with the entomological collection of the Institution and by the Phytophagous Insect Identification Center, Federal University of Paraná, Brazil.

The design were completely randomized and the data were analyzed through analysis of variance in the BIOSTAT program, which includes Tukey's test (5\%), to compare means of all variables and regression analyzes by orthogonal polynomials, to test each variable in time.

\section{Results and Discussion}

Was observed that the flowers open at 6:00 a.m. remaining open until about 12:00 p.m. when wither. Starting at 1:00 p.m. the female flowers begin to close gradually and soon after the male ones also close reducing the activity of pollinating agents. The flowers fall two days after opening regardless of whether they were fertilized or not.

The C. pepo female flower is easily distinguished due to its large ovary at the base of the flower with a thick style and three stigmatic wolves. The male flower has five stamens with filaments attached. Both male and female flowers produce nectar but the nectaries differ between the two types of flowers. In the male flower the nectary is located at the base of the filaments and the bees can access the nectar through three pores. In the female flower the nectary is opened forming a ring around the base of the style. In addition, Nepi et al. (2011) observed that the nectar of female flowers has significantly more sugars than male flower nectar (440 versus 325 $\mathrm{mg} / \mathrm{mL}$ ). Both types of flowers are feasible for at least one day with opening in the early morning and closing at noon. The peak of production of male and female flowers occurs about 60 to 66 days after planting with an average of 34.6 male flowers to 2.2 female flowers per plant (VIDAL et al., 2006).

The relationship between the number of male and female flowers (Figure 1) observed in the culture was 3.2:1 on average, in agreement with the data observed by Couto et al. (1990) founded seven times more male flowers compared to female flowers in Italian pumpkin.

The number of male flowers is always higher than female flowers in the Cucurbitaceae. These data demonstrate the diversity of this relationship between species and can be attributed to several factors such as soil conditions, climatic conditions and morphological differences between species. Bees prefer male flowers because of two factors, the first is that 
the male flower besides offering pollen also offers nectar to the visitors, and the second factor is that the number of male flowers in the
Cucurbitaceae in general is higher in relation to female flowers.

Figure 1. Male (A) and female (B) flower of the Italian pumpkin (Cucurbita pepo), in Ribeirão Preto, SP.

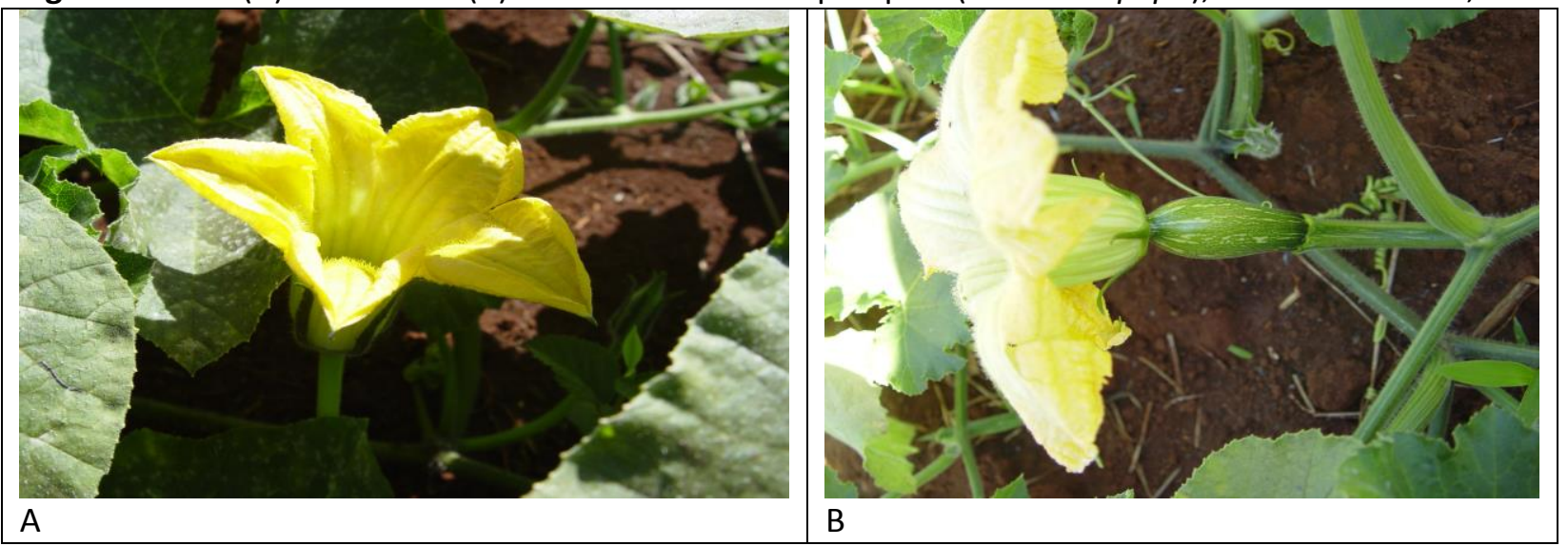

In the three years studied (2013, 2014 and 2015) was observed that the most frequent insect in the flowers of $C$. pepo was the Africanized honey bee Apis mellifera $(79.25 \% \pm$ 5,60 , on average, $p>0.05$ ) followed by the stingless bee Trigona spinipes $(20.75 \% \pm 2,15$, on average, $p>0.05)$. Sporadic visits of the squash specialist bee Peponapis fervens, two species of bees of the family Halictidae, Exomalopsis analis bees were observed however with a percentage of less than $1 \%$. These bee species were observed only a few times in cultivation in the three years evaluated. However, they are frequent bees in other plant species in the same experimental area.

Serra and Campos (2010) related $T$. spinipes, $T$. hyalinata, A. mellifera and Melipona quadrifasciata were the most frequent visitors of C. moschata flowers in Viçosa, MG. Krug et al. (2010) observed that the most abundant bee species was Africanized honey bee (32\%) followed by the squash specialist $P$. fervens $(25 \%)$ in Santa Catarina, Brazil. The squash specialist bee $P$. fervens as well as the others belonging to this genus has a specificity regarding the collection of pollen, restricting the collections of this resource only in Cucurbita flowers. Squash specialist bees $P$. fervens because they are experts in Cucurbita and depend on them for procreation, visit the flowers with high frequency and are excellent pollinators because they carry $100 \%$ of Cucurbita pollen on the pilosity of their body. $P$. fervens is very important for the reproductive success of the pumpkin as well as the resources provided by the plant are also of fundamental importance for the bee, since the pollen of this plant is the only source of food for their offspring. According to these authors the constancy, high visitation rate and the behavior of $P$. fervens in the flowers of Cucurbita should contribute to the proper cross-pollination of the flowers and consequently to the formation of fruits.

In the three studied years Africanized honey bees (Figure 2) to collect more nectar in male flowers $(61.0 \%$, on average) compared to pollen in male flowers $(22.3 \%$, on average) and nectar in female flowers (16.7\%, on average). These bees are the most managed species for honey production in the country (beekeeping) due to its resistance to diseases and adaptability and the amount of honey that it can produce (MORAIS et al., 2012).

The frequency of the Africanized honey bee in the male flowers collecting nectar increased up to 8:00 a.m. decreasing then. For pollen collection in male flowers, the frequency of $A$. mellifera increased up to 8:00 a.m. then decreased and for nectar collection in the flowers. In addition, the bees increased their frequency until 9:00 a.m. decreasing afterwards (Figure 3).

Nicodemo et al. (2009) observed that the peak of the presence of Africanized honeybee occurred at 8:00 a.m., of Trigona spp. between 9:00 am to 10:00 am and the Diabrotica speciosa coleopterous from 2:00 pm to 5:00 p.m. there being no overlap between these peak hours and an apparent strategy to avoid competition. In addition, Africanized honey bee used the flowers 
Figure 2. Africanized honey bee Apis mellifera collecting pollen on the male flower (A) and nectar (B) on the female flower of the Italian pumpkin (Cucurbita pepo) in Ribeirão Preto, SP.

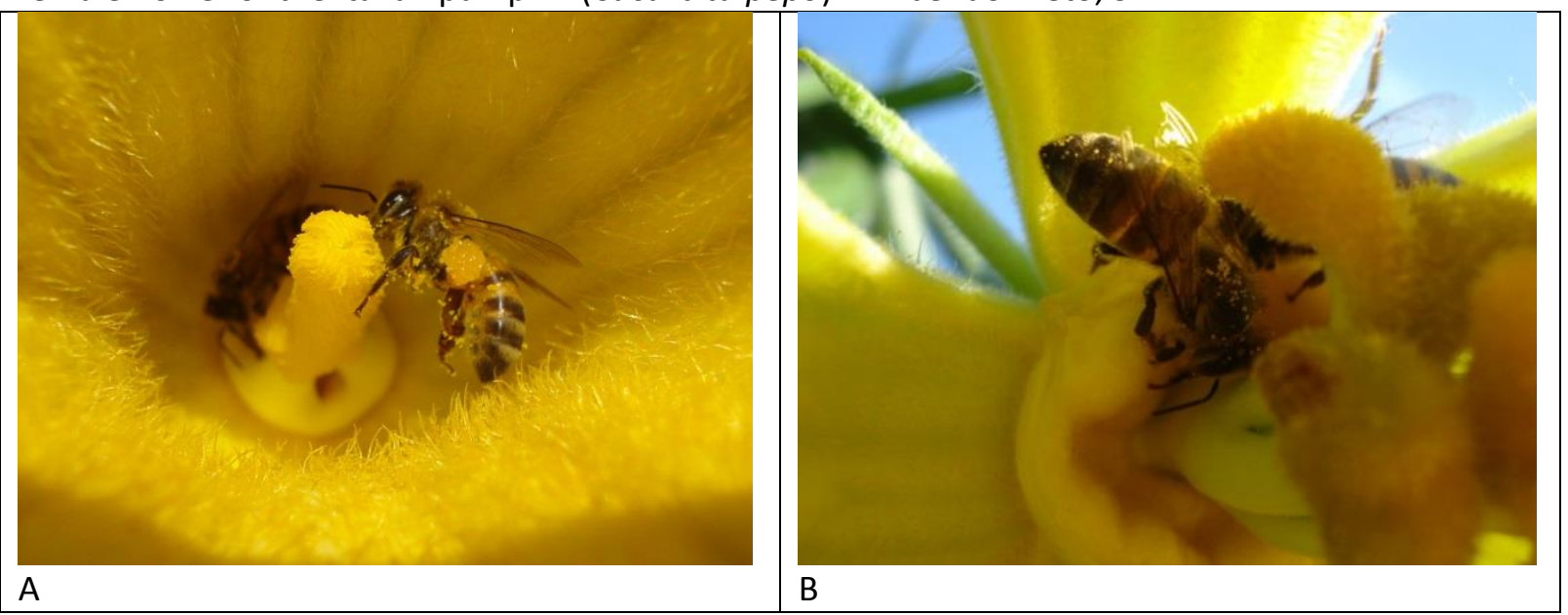

Figure 3. Frequency of Africanized honey bees Apis mellifera collecting nectar and pollen, in male and female flowers, in Italian pumpkin (Cucurbita pepo), in Ribeirão Preto, SP.

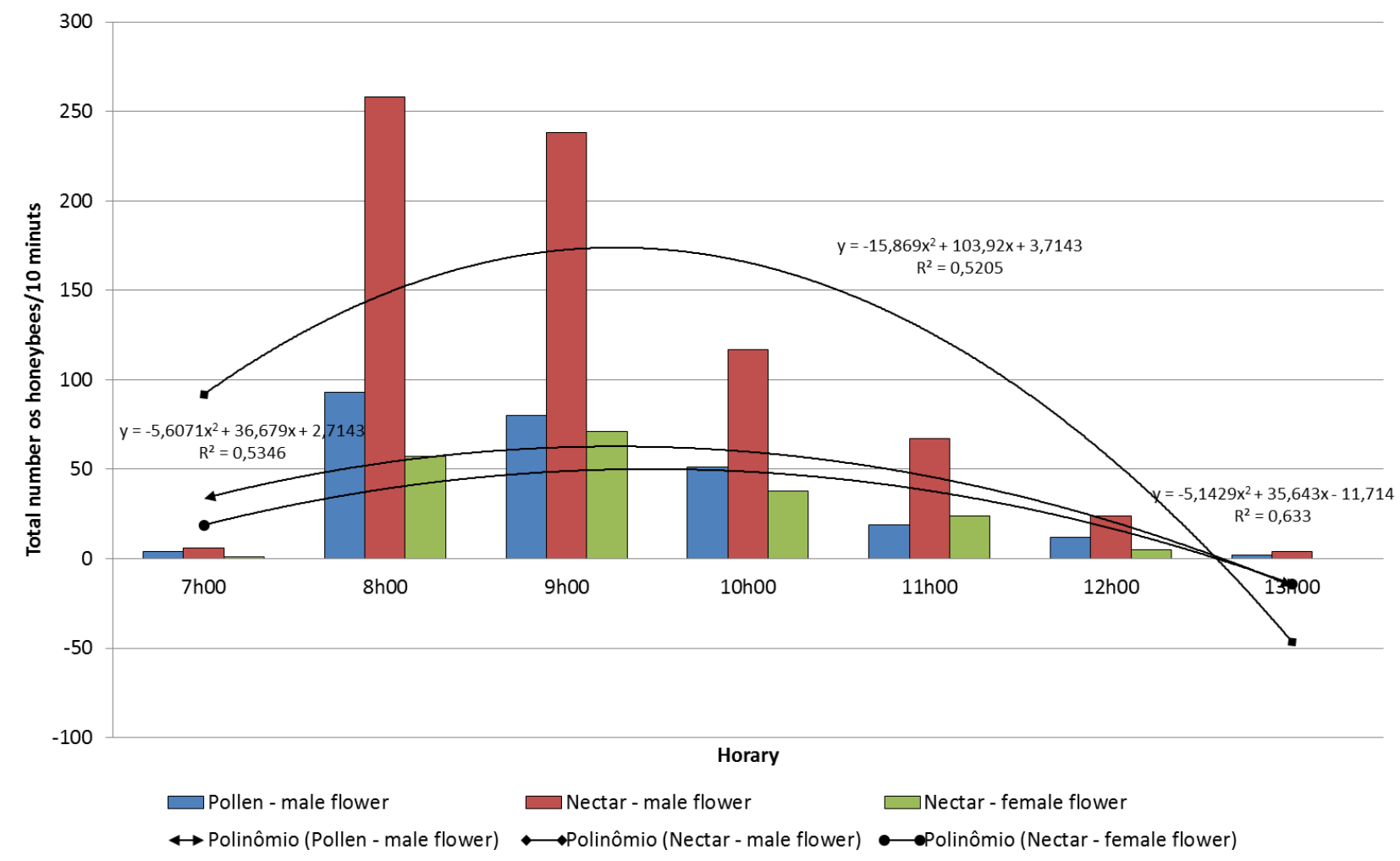

The pollen of C. pepo is large (80 to 150 $\mu \mathrm{m})$ and sticky, attributes associated with transport by biotic agents and the amount of pollen deposited on the stigma by bees varies according to the number of visits, from 53 grains with one visit, to 1,253 grains with 12 visits and number of grains at each visit ranged from 53 to 230 grains (VIDAL et al., 2010). Nicodemo et al. (2009) obtained a higher quantity of fruits when the number of visits of Africanized honey bee was 16 per female flower of the Italian pumpkin.

Stingless bees $T$. spinipes visited the flowers from 9:00 a.m. to 12:00 a.m. to collect nectar in female flowers (80.3\%) compared to nectar in male flowers (14.8\%) and pollen in male flowers (4.9\%). These bees presented a peak frequency of nectar collection between 9.00 a.m. and 11.00 a.m. (Figures 4 and 5). 
Figure 4. Stingless bee Trigona spinipes on the stigmas in the female flower on the Italian pumpkin (Cucurbita pepo) in Ribeirão Preto, SP.

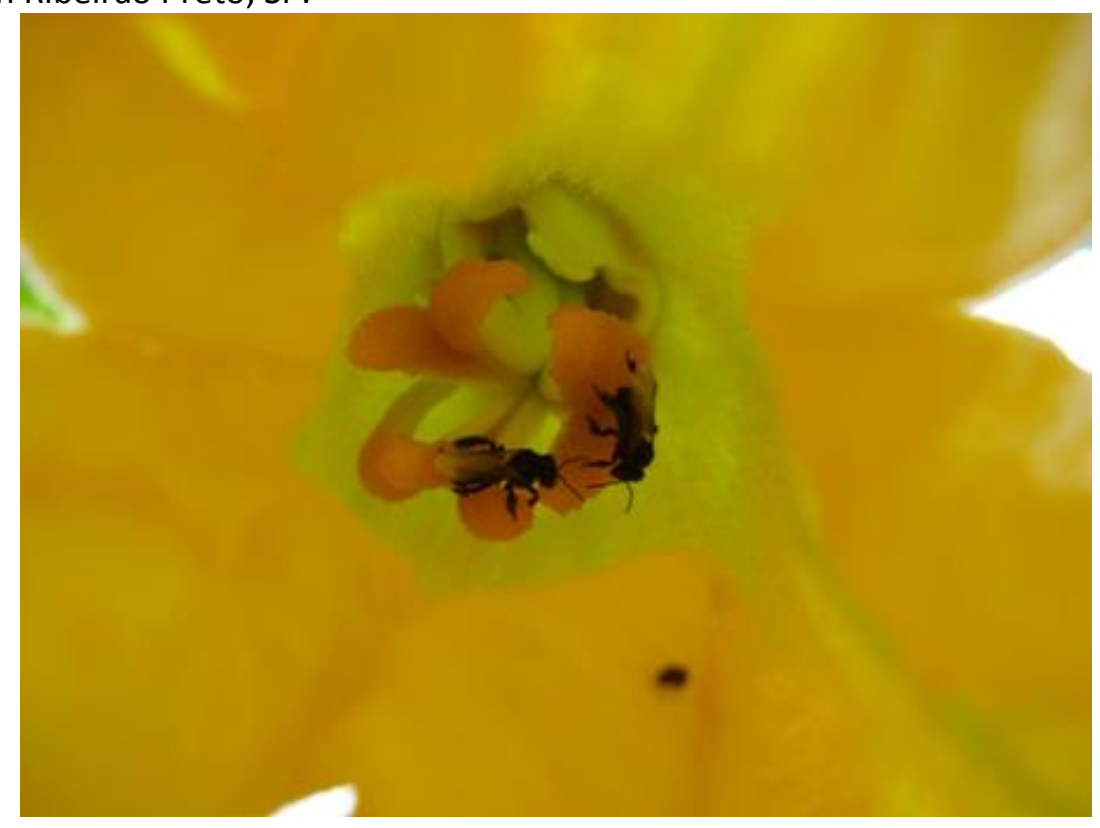

Figure 5. Average frequency of stingless bees Trigona spinipes collecting nectar and pollen, in female and male flowers, in Italian pumpkin (Cucurbita pepo) in Ribeirão Preto, SP.

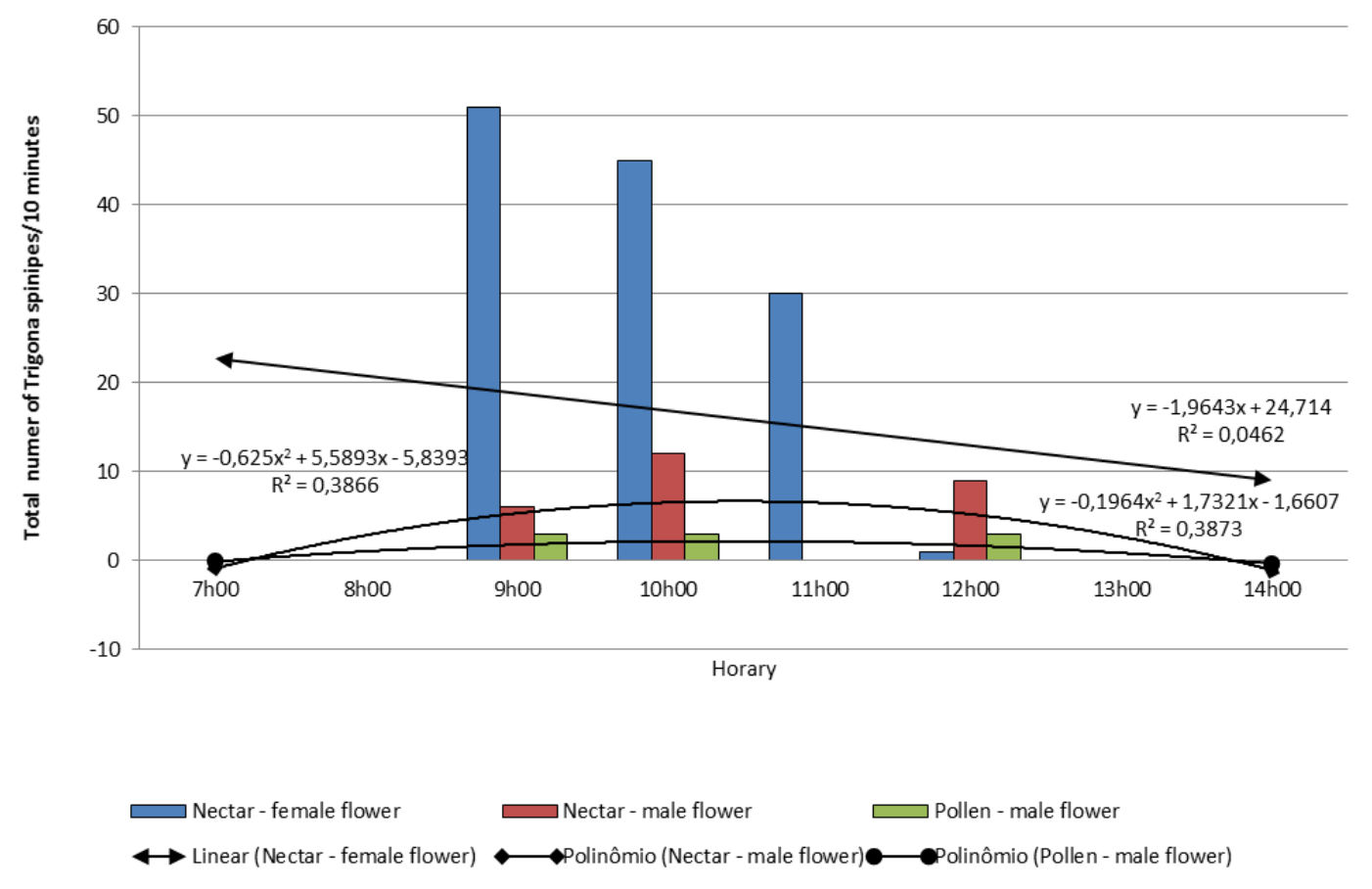

The native bee Exomalopsis analis was observed collecting nectar in female flowers only in 2014 (Figure 6). Squash specialist bees Peponapis fervens (Figure 7) were observed only collecting nectar in male flowers, however, Krug et al. (2010) reported this bee also collecting in female flowers. This bee was observed in all evaluated years but rarely compared to other bees. The same happened with the native bees of the Halictidae family, it was observed every year, rarely and only collecting nectar from male flowers (Figure 8). 
Figure 6. Native bee Exomalopsis analis collecting nectar in the female flower on the Italian pumpkin (Cucurbita pepo) in Ribeirão Preto, SP.

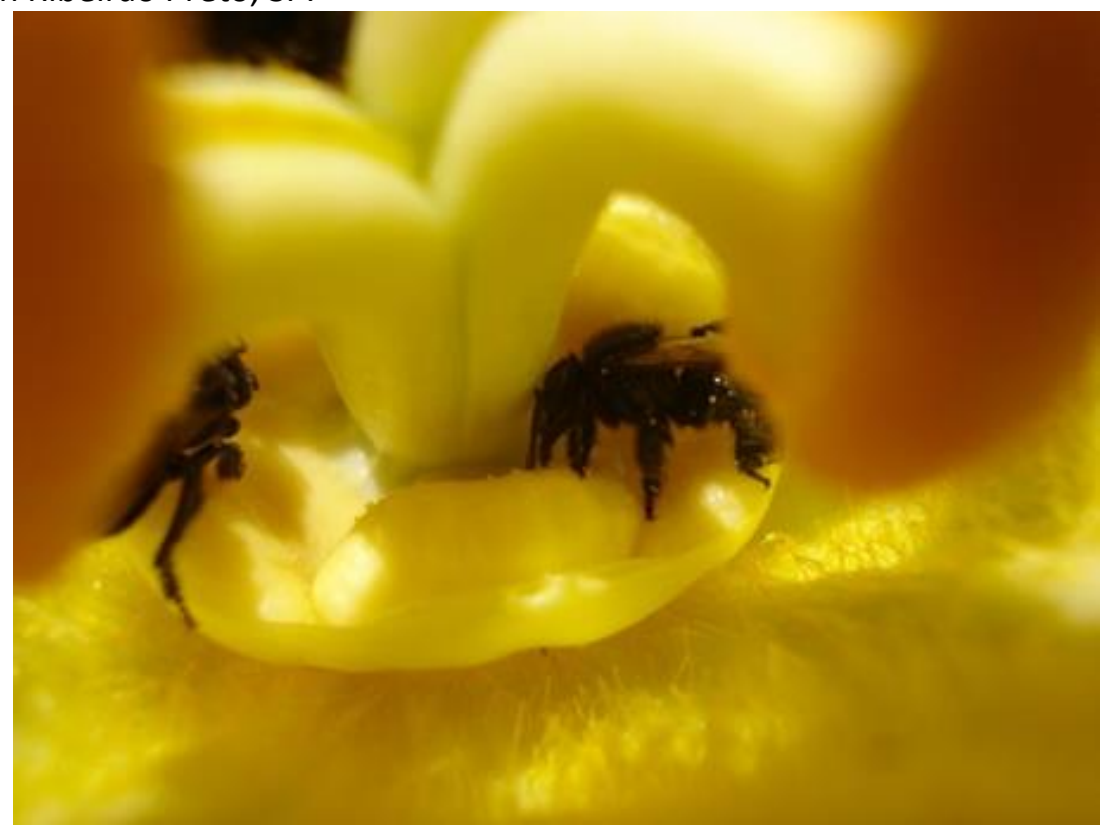

Figure 7. Squash specialist bees Peponapis fervens collecting nectar on the male flower of the Italian pumpkin (Cucurbita pepo) in Ribeirão Preto, SP.

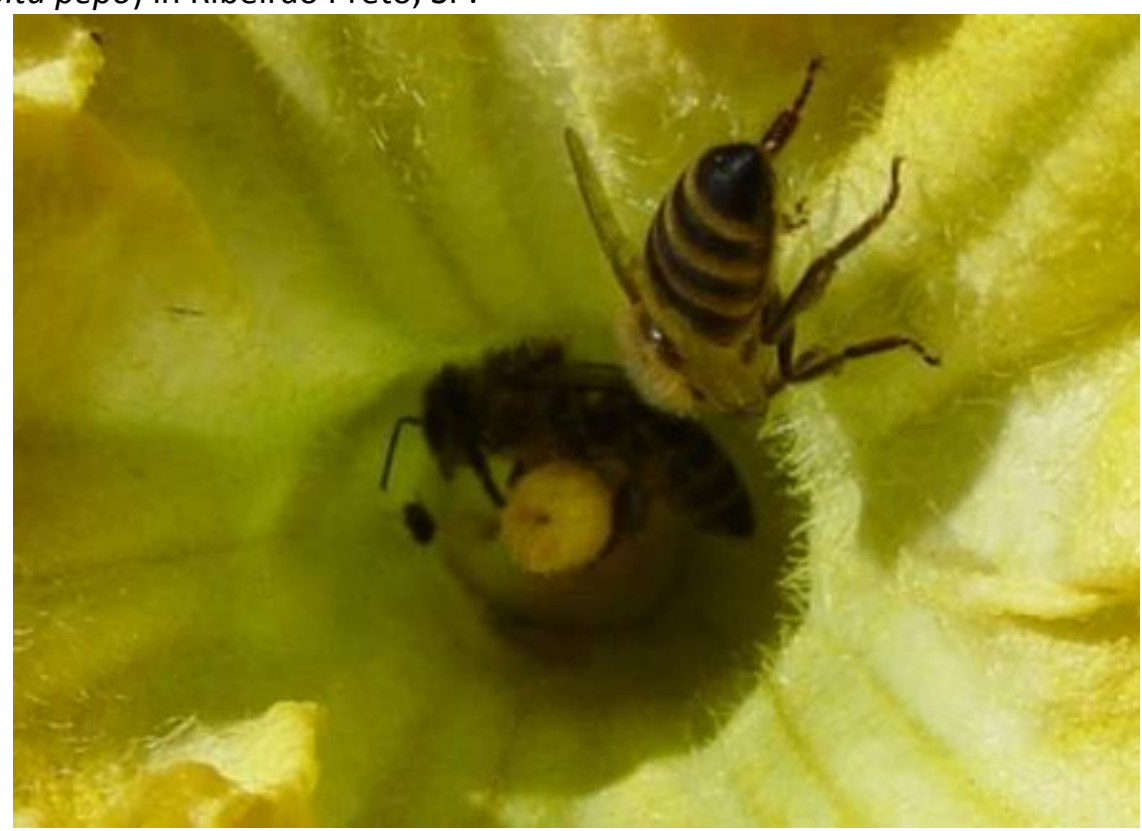


Figure 8. Native bees of the Halictidae family collecting nectar in the male flower of the Italian pumpkin (Cucurbita pepo) in Ribeirão Preto, SP.

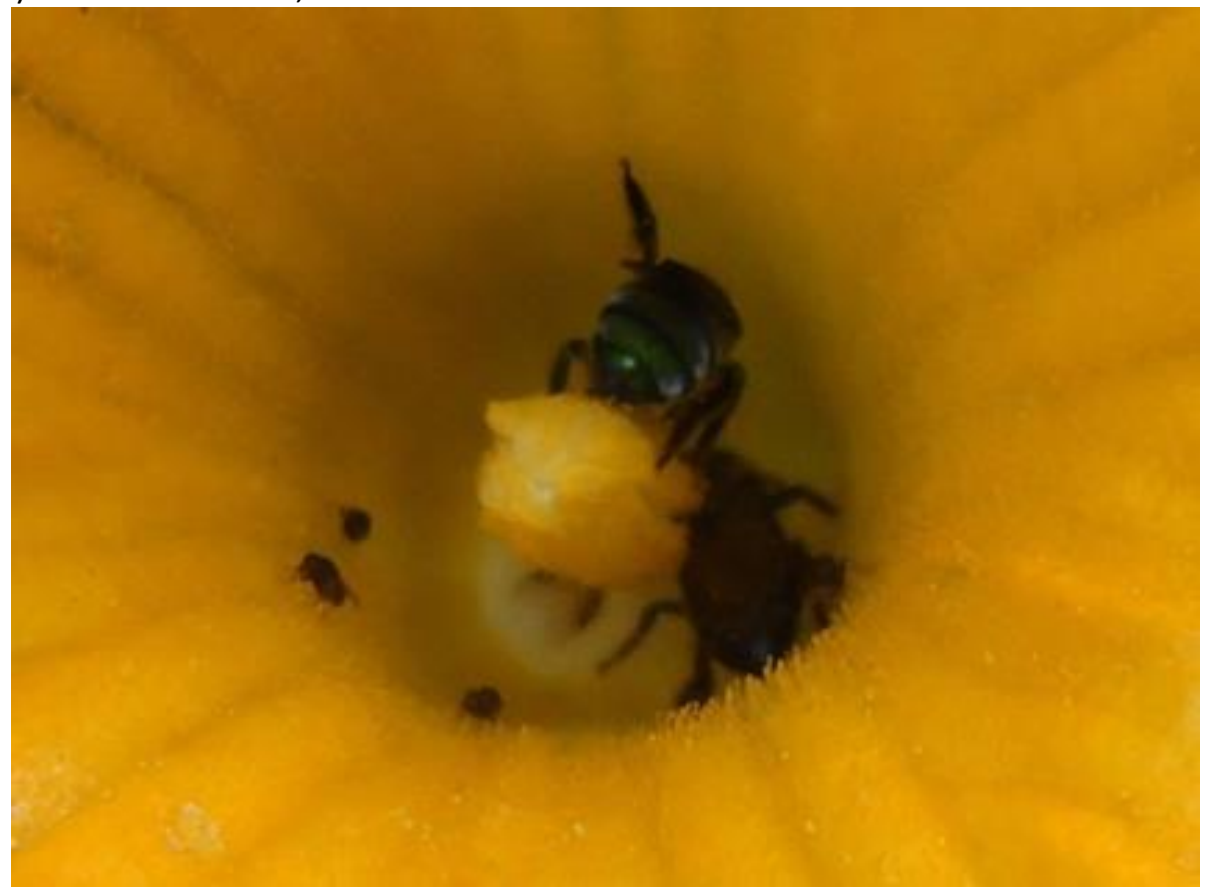

A large number of dipterous were observed inside the flowers with 11 flies for each male flower and 9.7 for each female flower. Even after the wilting some insects remained inside the flowers mainly Diptera and Coleoptera.

The Africanized honey bee presented the behavior of landed on the flower petals and walked to the corolla tube to access the nectar. In the staminate flowers, to access to the nectary was given by introducing the glossa in one of the three holes located between the fillets. The visitor often introduced the glossa in more than one hole at each visit, moving within the corolla and contacting different regions of the floral axis. In the female flower, the nectar accumulated around the base of the stylus and the access was made using the glossa. When collecting nectar, they positioned the body vertically between the corolla and the sexual structures of the flowers. In this position, with the back turned to the floral axis when visiting the staminate flowers, they touched the anthers and the pollen adhered to its body and, when visiting female flowers, this pollen was deposited on the stigma. After collecting the nectar, they left the flower repeating the same behavior in other flowers of the same individual or of different plants.

Stingless bees $T$. spinipes landed on the petal and then headed for the corolla tube, often without contacting the reproductive organs. In that case, by collecting nectar, they acted as stolen. At other times, they landed directly on the axis of the staminate or pistillate flower, and after landing they went to the base of the corolla where they collected nectar. In this case, pollen was present in their bodies that adhered when they landed directly on the stamens. These species moved through the petals, stamens or stigma, apparently in a disorderly way. They foraged in groups and monopolized food sources, chasing away other species that tried to land on the flowers they occupied.

Floral visitors are animals that seek resources in flowers for themselves or their offspring. Sometimes the same plant can receive a large spectrum of visitors, as is the case with species whose flowers offer a lot of nectar. However, not every floral visitor pollinates (SANTOS et al., 2016). Costanza et al. (2017) reported to be classified as a pollinator of a plant species is necessary that the potential pollinator be attracted by the flowers of the crop; that shows fidelity to that species; that has the appropriate size and behavior to remove pollen from the stamens and deposit them in the stigmas that carry in your body a lot of viable and compatible pollen and that visit the flowers when the stigmas have good receptivity. In cucurbits, which have separate male and female flowers, pollinators provide egg fertilization and consequent fruit formation with their seeds. Africanized honey bee had all these 
requirements. They are efficient pollinators in a tropical climate, moving quickly, zigzagging, inflorescences when collecting nectar and pollen, making pollen dispersion more efficient. Moreover, in this experiment, was constanty species in the flowers of the Italian pumpkin. Rani et al. (2016) indicated that honey bees as well as wild pollinators were essential for pollination of C. pepo flowers and thus increasing fruit size and yield.

These results prove the importance of preserving pollinators, especially bees, whether Africanized or native ones. There is a need for farmers to be aware of this. These farmers can preserve and reforest our forests, keeping the native bee species so important in agricultural production. To this day many farmers kill solitary bees like Xylocopa spp., pollinators of passion fruit, thinking they are beetles. These results need to be made known to these farmers and they must be aware of and responsible for the maintenance of all bee species. Moreover, deforestation, burning and the intensive use of agricultural pesticides cause destruction of the natural habitat of pollinators and poison both bees and their products: honey and pollen that we consume. Extension actions are needed showing farmers the importance of pollinators to their agricultural crops and their lives (MALERBO-SOUZA et al., 2018).

Wolowski et al. (2019) using data from the Thematic Report on Pollination, Pollinators and Food Production in Brazil, showed that bees are the largest group of pollinators and account for about $48 \%$ of all species identified as floral visitors of crops linked to food production. These species are associated with 132 (92\%) crops, being recognized as pollinators of 91 of them and constituting exclusive pollinators of 74 . Cultures with high economic value such as soybean (Glycine max), coffee (Coffea arabica), apple (Malus domestica), onion (Allium cepa), melon (Cucumis melo), tomato (Solanum lycopersicum) and bean (Phaseolus spp.) are pollinated by bees. The Africanized honey bee and stingless bees predominate in the records as floral visitors and pollinators of crops related to food production. Africanized honey bee is associated with 86 crops, being pollinator potential of 54 , while stingless bees have been registered as floral visitors of 107 crops and as pollinators of 52 . Native stingless bees belonging to the Apidae family and to the Meliponini tribe have tropical distribution and in
Brazil there are more than 400 described species (PEDRO, 2014).

\section{Conclusions}

Several bee species collect nectar and pollen from pumpkin flowers: Africanized honey bees Apis mellifera, stingless bees Trigona spinipes, native bees Exomalopsis analis, Peponapis fervens and species of the family Halictidae. The Africanized honey bee was the most frequent and constanty insect observed in the flowers of the Italian pumpkin. The flowers of this culture were open until 1:00 p.m. after all the flowers remained closed. Africanized honey bees collected both nectar and pollen on the male and female flowers of the pumpkin visiting them throughout the period.

\section{References}

SANTOS, I. A dos.; SILVA, C. I. da; PINHEIRO, M.; KLEINERT, A. M. P. Quando um visitante floral é um polinizador? Rodriguésia, v.67, n.2, p. 295307, $2016 . \quad$ http://dx.doi.org/10.1590/21757860201667202

ARTZ, D. R.; NAULT, B. A. Performance of Apis mellifera, Bombus impatiens, and Peponapis pruinosa (Hymenoptera: Apidae) as pollinators of pumpkin. Journal of Economic Entomology, v.104, n.4, p. 1153-1161, 2011.

https://dx.doi.org/10.1603/ec10431

ÁVILA, C. J.; MARTINHO, M. R.; CAMPOS, J. P. Polinização e polinizadores na produção de frutos e sementes híbridas de abóbora (Cucurbita pepo var. melopepo). Anais da Sociedade Entomológica do Brasil, v.18, n. 1, p. 13-19, 1989.

BARÔNIO, G. J.; MACIEL, A. A.; OLIVEIRA, A. C.; KOBAL, R. O. A. C.; MEIRELES, D. A. L.; BRITO, V. L. G.; RECH, A. R. Plantas, polinizadores e algumas articulações da biologia da polinização com a teoria ecológica. Rodriguésia, v.67, n.2, p. 275293, 2016. https://dx.doi.org/10.1590/21757860201667201

COSTANZA, R.; D'ARGE, R.; GROOT, R. The value of the world's ecosystem services and natural capital. Nature, v.387, p. 253-260, 1997.

COSTANZA, R.; GROOT, R.; BRAAT, L.; KUBISZEWSKI, I.; FIORAMONTI, L.; SUTTON, P.; FARBER, S.; GRASSO, M. Twenty years of ecosystem services: how far have we come and how far do we still need to go? Ecosystem 
Services, v.28, p. 1-16, 2017.

https://dx.doi.org/10.1016/j.eco-

ser.2017.09.008

COUTO, R. H. N.; PEREIRA, J. M. S.; COUTO, L. A. Estudo da polinização entomófila em Cucurbita pepo (abóbora italiana). Científica, v.18, n.1, p. 21-27, 1990.

GALLAI, N.; SALLES, J. M.; SETTELE, J.; VAISSIÈRE, B. E. Economic valuation of the vulnerability of world agriculture confronted with pollinator decline. Ecological Economics, v.68, n.3, p. 810821, 2009.

https://dx.doi.org/10.1016/j.ecolecon.2008.06.01 4

GIANNINI, T. C.; CORDEIRO, G. D.; FREITAS, B. M.; SARAIVA, A. M.; IMPERATRIZ-FONSECA, V. L. The dependence of crops for pollinators and the economic value of pollination in Brazil. Journal of Economic Entomology, v.108, n.3, p. 849-857, 2015. https://dx.doi.org/10.1093/jee/tov093

IPBES. The assessment report of the inter governmental science-policy platform on biodiversity and ecosystem services on pollinators, pollination and food production. Germany: Secretariat of the Intergovernmental Science-Policy Platform on Biodiversity and Ecosystem Services, 2016. 552 p.

KLEIN, A. M.; VAISSIERE, B. E.; CANE, J. H.; STEFFAN-DEWENTER, I., CUNNINGHAM, S. A.; KREMEN, C.; TSCHARNTKE, T. Importance of pollinators in changing landscapes for world crops. Proccedings of Royal Society, v.274, p. 303-313, 2007.

https://dx.doi.org/10.1098/rspb.2006.3721

KRUG, C.; SANTOS, I. A. dos; CANE, J. Visiting bees of Cucurbita flowers (Cucurbitaceae) with emphasis on the presence of Peponapis fervens smith (Eucerini-Apidae)-Santa Catarina, Southern Brazil. Oecologia Australis, v.14, n.1, p. 128-139, 2010.

https://dx.doi.org/10.4257/oeco.2010.1401.06

LATTARO, L. H.; MALERBO-SOUZA, D. T. Polinização entomófila em abóbora caipira, Cucurbita mixta (Cucurbitaceae). Acta Scientiarum Agronomy, v.28, n.4, p. 563-568, 2006.
MALERBO-SOUZA, D. T.; SILVA, T. G. da; ANDRADE, M. O.; FARIAS, L. R.; MEDEIROS, N. M. $G$. Factors affecting the foraging behavior of bees in different maize hybrids. Revista Brasileira de Ciências Agrárias, v.13, n.3, 2018.

https://dx.doi.org/10.5039/agraria.v13i3a5551

MORAIS, M. M.; DE JONG, D.; MESSAGE, D.; GONÇALVES, L. S. Perspectivas e desafios para o uso das abelhas Apis mellifera como polinizadores no Brasil. In: FONSECA, V. L. I.; CANHOS, D. A. L.; ALVES, A. A.; SARAIVA, A. M.; (orgs.). Polinizadores no Brasil: contribuição e perspectivas para a biodiversidade, uso sustentável, conservação e serviços ambientais. São Paulo: Editora da Universidade de São Paulo, 2012. p. 203-236.

NEPI, M.; CRESTI, L.; GUARNIERI, M.; PACINI, E. Dynamics of nectar production and nectar homeostasis in male flowers of Cucurbita pepo L. International Journal of Plant Sciences, v.172, n.2, p. 183-190, 2011.

https://dx.doi.org/10.1086/657648

NICODEMO, D.; COUTO, R. H. N.; MALHEIROS, E. B.; JONG, D. Honey bee as an effective pollinating agent of pumpkin. Scientia Agricola, n.66, p. 476480, 2009. http://dx.doi.org/10.1590/S010390162009000400007

OLLERTON, J.; WINFREE, R.; TARRANT, S. How many flowering plants are pollinated by animals? Oikos, v.120, p. 321-326, 2011.

https://dx.doi.org/10.1111/j.1600-

0706.2010.18644.x

PEDRO, S. R. M. The stingless bee fauna in Brazil (Hymenoptera: Apidae). Sociobiology, v.61, p. 348-354, 2014.

http://dx.doi.org/10.13102/sociobiology.v61i4.34 8-354

RANI, D. D.; YADAV, S.; KAUSHIK, H. D.; KUMAR, G. N. Effect of different modes of pollination on yield parameters of summer squash (Cucurbita pepo L.) in India. Journal of Applied and Natural Science, v.8, n.2, p. 550-554, 2016. http://dx.doi.org/10.31018/jans.v8i2.834

ROUBIK, D. W. The pollination of cultivated plants: a compendium for practitioners. 2. ed. Roma: FAO, 2018. 
SERRA, B. D. V.; CAMPOS, L. A. O. Polinização entomófila de abobrinha, Cucurbita moschata (Cucurbitaceae). Neotropical Entomology, v.39, n.2, p. 153-159, 2010.

http://dx.doi.org/10.1590/S1519-

566X2010000200002

SILVEIRA NETO, S.; NAKANO, O.; BARBIN, D.; VILLA NOVA, N. A. Manual de ecologia dos insetos. Piracicaba: Agronômica Ceres, 1976.

VIDAL, M. D. G.; DE JONG, D.; WIEN, H. C.; MORSE, R. A. Nectar and pollen production in pumpkin (Cucurbita pepo L.). Revista Brasileira de Botânica, v.29, n.2, p. 267-273, 2006.

http://dx.doi.org/10.1590/\$0100-

84042006000200008

VIDAL, M. D. G.; DE JONG, D.; WIEN, H. C.; MORSE, R. A. Pollination and fruit set in pumpkin (Cucurbita pepo) by honey bees. Revista Brasileira de Botânica, v.33, n.1, p. 106-113, $2010 . \quad$ http://dx.doi.org/10.1590/S010084042010000100010

WOLOWSKI, M.; AGOSTINI, K.; RECH, A. R.; VARASSIN, I. G.; MAUÉS, M.; FREITAS, L.; CARNEIRO, L. T.; BUENO, R. O.; CONSOLARO, H.; CARVALHEIRO, L.; SARAIVA, A. M.; SILVA, C. I. Relatório temático sobre polinização, polinizadores e produção de alimentos no Brasil. Espiríto Santo: REBIPP, 2019. 